\title{
Phosphodiesterase 4 and Its Inhibitors in Inflammatory Diseases
}

\author{
S.-L. Catherine Jin, PhD; Shiau-Li Ding, MS; Shih-Chang Lin ${ }^{1}, \mathrm{MD}, \mathrm{PhD}$
}

Type 4 cyclic nucleotide phosphodiesterases (PDE4) are a family of low $k_{m}$ 3',5' -cyclic adenosine monophosphate (cAMP)-specific phosphodiesterases including at least 20 isozymes encoded by four genes (PDE4A, PDE4B, PDE4C, and $P D E 4 D)$ in mammals. Each PDE4 gene plays a special, nonredundant role in the control of cell function even though the four subfamilies share the highly conserved catalytic domain and upstream conserved region (UCR) 1 and UCR2 motifs of the

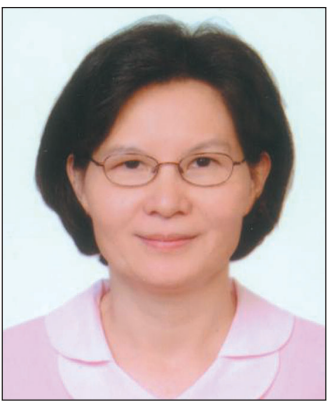

Prof. S.-L. Catherine Jin

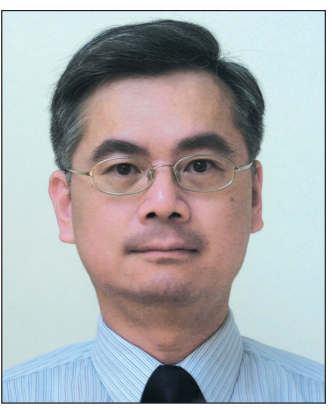

Dr. Shih-Chang Lin regulatory domain. By their wide tissue distribution as well as differential expression and regulation among various cell types, PDE4s are viewed as critical regulators of intracellular cAMP levels, cAMP signaling, and signal compartmentalization. By increasing cAMP levels, PDE4 inhibitors show a broad spectrum of anti-inflammatory effects in almost all inflammatory cells. Many PDE4 inhibitors have been evaluated in clinical trials for various inflammatory conditions. Developed inhibitors, including the recently approved and marketed roflumilast, have considerable efficacy, but they also have adverse effects such as nausea and emesis which limit their dosing and subsequently their immunomodulatory activity. Thus, the development of PDE4 inhibitors with improved therapeutic indexes has been a major focus of pharmaceutical research for the treatment of chronic inflammatory diseases. Recent PDE4 gene knockout studies strongly suggest that PDE4 inhibitors with PDE4B selectivity may retain the anti-inflammatory effects while limiting side effects. Development of PDE4 inhibitors with different delivery routes, such as topical application and inhalation, is also a promising approach for the treatment of pulmonary inflammatory conditions and dermatitis. This review includes a brief overview of the domain structure and function of PDE4 isozymes, the role of PDE4s in inflammatory cell responses, and the potential therapeutic utility of PDE4 inhibitors in inflammatory diseases. (Chang Gung Med J 2012;35:197-210)

Key words: PDE4, inflammation, asthma, COPD, cAMP signaling

\footnotetext{
From the Department of Life Sciences, National Central University, Jhongli, Taoyuan, Taiwan; 'Division of Allergy and Immunology, Department of Internal Medicine, Cathay General Hospital, Taipei, Taiwan.

Received: Oct. 12, 2011; Accepted: Dec. 12, 2011

Correspondence to: Prof. S.-L. Catherine Jin, Department of Life Sciences, National Central University. 300, Jhongda Rd., Jhongli City 320, Taoyuan, Taiwan (R.O.C.) Tel: 886-3-4227151 ext. 65066; Fax: 886-3-4228482; E-mail: slcj@ncu.edu.tw

Correspondence to: Dr. Shih-Chang Lin, Division of Allergy and Immunology, Department of Internal Medicine, Cathay General Hospital. 280, Renai Rd. Sec. 4, Taipei 106, Taiwan (R.O.C.) Tel: 886-2-27082121 ext. 3210; Fax: 886-2-27082121 ext. 3211 ;

E-mail: sclin@cgh.org.tw
} 
$\mathrm{S}$ ince Sutherland and Rall identified the enzymatic activity of cyclic nucleotide phosphodiesterases (PDEs) in 1958, ${ }^{(1)}$ continuing efforts have been devoted to advancing our understanding of the cell biology and functions of these enzymes. These efforts include biochemical and structural characterization, pharmacological implication, molecular cloning and sequencing, interacting protein identification, intracellular targeting and compartmentalization. PDEs are a superfamily of enzymes catalyzing the hydrolysis of 3',5'-cyclic adenosine monophosphate (cAMP) and 3',5'-cyclic guanosine monophosphate (cGMP) to their inactive 5'-AMP and 5'-GMP. Cyclic nucleotides are known to play pivotal roles in a myriad of cellular functions including immune and inflammatory responses, ${ }^{(2)}$ cardiac activities such as heart rate and contractility, smooth muscle relaxation, energy homeostasis, fluid homeostasis, visual excitation, depression, cognition, oocyte maturation, and apoptosis. ${ }^{(3)}$ Thus, as a central regulator of intracellular concentrations of cyclic nucleotides, PDEs have been considered pharmocologic targets for various disease therapies, such as for congestive heart failure, ${ }^{(4-6)}$ intermittent claudication, ${ }^{(7,8)}$ erectile dysfunction, ${ }^{(9,10)}$ chronic obstructive pulmonary disease (COPD), ${ }^{(11,12)}$ asthma, ${ }^{(2,13)}$ depression, ${ }^{(14)}$ and schizophrenia. ${ }^{(15,16)}$

To date, a total of 21 PDE genes have been identified in mammals and are classified into eleven families, called PDE1-11 based on their substrate specificity and affinity, primary sequence homology, inhibitor selectivity, and regulation by specific activators. ${ }^{(17-20)}$ Among these, PDEs 4, 7, and 8 are selective for cAMP, PDEs 5, 6, and 9 for cGMP, and the other PDE families for both cAMP and cGMP. PDEs $1,3,4,6,7$ and 8 are encoded by more than one gene, while the other families are each encoded by only one gene. Most PDE genes code for multiple variants derived from alternative splicing and the use of different promoters, ${ }^{(21,22)}$ and as a result, more than 100 distinct PDE transcripts are likely to be present in any mammalian species. ${ }^{(20,23)}$

The mammalian PDEs contain a highly conserved catalytic domain located near the carboxylterminal half of the protein and a divergent regulatory domain towards the amino-terminal portion of the protein. A $\mathrm{HN}\left(\mathrm{X}_{2}\right) \mathrm{HN}\left(\mathrm{X}_{\mathrm{n}}\right) \mathrm{E} / \mathrm{D} / \mathrm{Q}\left(\mathrm{X}_{10}\right) \mathrm{HD}\left(\mathrm{X}_{2}\right) \mathrm{H}\left(\mathrm{X}_{25}\right) \mathrm{E}$ motif conserved in the catalytic domain represents two consensus metal binding domains that are com- monly found in proteases such as matrix metalloproteinases. ${ }^{(18,20)}$ The regulatory domains are conserved within each family. The conserved regions include $\mathrm{Ca}^{2+/ c a l m o d u l i n}$ binding domains for PDE1, upstream conserved regions (UCR) for PDE4, cGMP-activated PDEs, adenylyl cyclase, and Fh1A (GAF) domains for PDE6 as well as in PDEs 2, 5, 10, and 11, the Per-Arnt-Sim domain for PDE8, phosphorylation sites for kinases, and protein-protein interaction domains. ${ }^{(3,22)}$ The carboxyl-terminal sequence is divergent among the PDEs but phosphorylation ${ }^{(24-26)}$ and posttranslational modifications ${ }^{(27)}$ have been reported in this region.

In this review we will provide a brief overview of the molecular characteristics of PDE4 isozymes and the role of these enzymes in regulation of inflammatory cell responses. The potential therapeutic utility of PDE4 inhibitors in inflammatory diseases will also be discussed.

\section{The PDE4 family}

The PDE4 family in mammals is composed of four subfamilies, which are encoded by four paralog genes (PDE4A, PDE4B, PDE4C and PDE4D). More than 20 PDE4 variants are present in cells arising from alternative mRNA splicing or the use of different transcriptional units. ${ }^{(21,28)}$ These PDE4 isozymes share a highly conserved catalytic domain of approximately 320-350 amino acids with more than $80 \%$ sequence identity between the members of the four isotypes. ${ }^{(29-31)}$ The sequences of the $\mathrm{N}$-terminus regulatory domains among the four subfamilies are divergent except for those in the two upstream conserved regions (UCR1 and UCR2), which are unique to the PDE4 proteins. ${ }^{(32)}$ The four subfamily isozymes can be subgrouped into three forms: the 'long' forms which contain both UCR1 and UCR2, the 'short' forms which lack UCR1, and the 'super-short' forms which contain only the C-terminal portion of UCR2. ${ }^{(33)}$ The C-terminal sequence of the PDE4 enzymes is divergent and their functional significance remains to be defined.

UCR 1 and UCR2 are functional modules of approximately 60 and 80 residues, respectively. ${ }^{(29,32)}$ UCR2 bears an autoinhibitory nature, a property inferred from observations that removal of a portion of this domain causes an increase in the catalytic activity of the enzyme. ${ }^{24,30,34)}$ UCR 1 contains a protein kinase A (PKA) phosphorylation site. Elevation 
of cAMP levels in cells induces phosphorylation of its serine residue by PKA, which then leads to a rapid activation of PDE4 as well as increases in the sensitivity of the enzyme to the PDE4 inhibitor rolipram, as demonstrated in PDE4D3. ${ }^{(35,36)}$ Experiments have further indicated that PDE4 activation led by PKA phosphorylation in UCR 1 may be the consequence of relieving the inhibitory constraint of UCR2 on the catalytic domain. ${ }^{(34)}$ Moreover, a potentially electrostatic intramolecular interaction between UCR1 and UCR2 has been described in PDE4D3. ${ }^{(37)}$ Phosphorylation of UCR1 appears to disrupt this interaction. ${ }^{(37)}$

Evidence also indicates that UCR 1 and UCR2 in PDE4 long forms can interact intermolecularly, thus leading to PDE4 dimerization, whereas short forms lacking UCR1 are monomers. ${ }^{(38,39)}$ PKA phosphorylation of UCR1 does not interfere with this interaction. The dimerization takes place between the C-terminal region of UCR1 and the N-terminal region of UCR2 as deletion of either part leads to failure of PDE4 dimerization. Disruption of dimerization abrogates the activation of PDE4D3 by PKA phosphorylation as well as reduces the sensitivity of the enzyme to rolipram. ${ }^{(38,39)}$

\section{Expression of PDE4 in inflammatory cells}

The PDE4 isozymes are widely distributed in mammalian cells and tissues, implicating the diverse biological function of these proteins. PDE4s are the predominant cAMP-degrading isozymes in most, if not all, immune and inflammatory cells, including $\mathrm{T}$ cells, B cells, eosinophils, neutrophils, dendritic cells, monocytes, and macrophages. ${ }^{(2)}$ Three PDE4 subtypes, PDE4A, PDE4B and PDE4D, are expressed in these cells, while PDE4C is minimal or absent. ${ }^{(13,40)}$ PDE3 and PDE7 are also detected in most of the inflammatory cells. ${ }^{(13,40)}$ The expression levels of these PDE isozymes are differentially regulated by a variety of inflammatory stimuli. As demonstrated in Jurkat T-cells and human peripheral blood T-cells, 8-Bromo-cAMP or prostaglandin E2 evidently induces PDE3 and PDE4 enzyme activity, and this effect is associated with increased PDE3B, PDE4A4, PDE4A1, 4D2, and 4D3 mRNA expression. ${ }^{(41)}$ Stimulation of human peripheral blood cluster of differentiation $4^{+} \mathrm{T}\left(\mathrm{CD}^{+} \mathrm{T}\right)$ cells with anti-CD3 and anti-CD28 antibodies also regulates the expression of PDE4 subtypes differentially, with PDE4A and
PDE4D mRNAs upregulated along with enzyme activity within 5 days but PDE4B mRNA upregulated transiently with highest levels at $24 \mathrm{~h}$ after stimulation. ${ }^{(42)}$ In addition, lipopolysaccharide (LPS) has been shown to selectively induce PDE4B2 mRNA expression in human circulating monocytes. ${ }^{(43)}$ This regulation of PDE4B expression has been confirmed in monocytes and peritoneal macrophages of PDE4 knockout mice. ${ }^{(44,45)}$ Among 12 PDE4 isozymes tested, PDE4A4 and PDE4B2 were detected at higher levels in peripheral blood monocytes of smokers compared with nonsmokers. ${ }^{(46)}$ Moreover, PDE4A4 transcripts were found significantly upregulated in alveolar macrophages from smokers with COPD compared with smokers without COPD. ${ }^{(46)}$ Although the functional consequences of the PDE4 regulation remain to be determined, these PDE4 isozymes altered in pathophysiological processes may serve as potential therapeutic targets for a variety of inflammatory conditions.

\section{PDE4 and inflammation}

To date, our understanding of the cellular functions of PDE4 has been mostly derived from experiments involving PDE4 inhibitors. These small molecule compounds, including the prototype inhibitor rolipram and second-generation compounds such as roflumilast and cilomilast, have been shown to produce a wide range of pharmacological effects in vitro and in vivo. These include antiinflammatory and immunomodulatory effects, ${ }^{(2,13,47-50)}$ antidepressant and antischizophrenia actions, ${ }^{(14,15,51)}$ and cognitive enhancement, ${ }^{(52,53)}$ clearly demonstrating a broad, critical role of PDE4 in cellular and physiological functions. Among these effects, the inflammatory aspect of PDE4 functions has been explored most extensively. In fact, PDE4 is the major family of PDE enzymes expressed in immune and inflammatory cells. Inhibition of PDE4 has been shown to suppress a diverse spectrum of inflammatory responses in vitro and in vivo. ${ }^{(2,13,40)}$ More importantly, many PDE4 inhibitors in development are efficacious in animal models of various inflammatory disorders, such as asthma, COPD, psoriasis, inflammatory bowel diseases, and rheumatoid arthritis, ${ }^{(13,54)}$ as well as in clinical trials for asthma and COPD (see below). ${ }^{(11,55,56)}$ These data thus provide strong evidence that PDE4 is a valid, promising drug target for different inflammatory conditions. 


\section{The non-selective PDE inhibitor theophylline}

The nonselective PDE inhibitor theophylline, a methylxanthine drug, has been used in therapy for respiratory diseases such as asthma and COPD for almost 90 years. ${ }^{(57-59)}$ Although initially recognized as a PDE inhibitor, theophylline is also known as a potent adenosine receptor antagonist ${ }^{(60,61)}$ and an activator of histone deacetylase 2 (HDAC2). ${ }^{(62)}$ It is thought that the beneficial effects of theophylline on asthma and COPD are largely due to its antiinflammatory properties. Several mechanisms have been proposed for such effects, which include (1) increasing intracellular cAMP concentrations via inhibition of PDE (mainly PDE4), ${ }^{(263)}$ (2) decreasing inflammatory gene expression through inducing HDAC activity, ${ }^{(62)}$ and (3) reversal of corticosteroid resistance by inhibiting oxidative stress dependent phosphoinositide 3 kinase $\delta .{ }^{(64,65)}$ In clinical practice, theophylline is known to interact with a number of drugs, such as cimetidine and phenytoin, and have a narrow therapeutic window. It causes a myriad of side effects at higher doses including nausea, diarrhea, headache, insomnia, increased heart rate, and arrhythmias. ${ }^{(66,67)}$ These disadvantages together with its relatively low efficacy compared with inhaled glucocorticoids or $\beta_{2}$-agonists have limited its usage in asthmatic patients. Because of its nonselectivity towards most of the PDEs expressed in body cells, the pharmaceutical industry has devoted massive efforts in developing inhibitors selective for PDE4s, the isozymes expressed predominantly in proinflammatory cells. ${ }^{(68,69)}$ In fact, PDE4 inhibitors are considered promising therapeutic agents because of their prominent antiinflammatory effects (detailed below).

\section{PDE4 inhibitors}

Numerous PDE4 selective inhibitors have been patented in the past two decades, and some of them have been evaluated in clinical trials for several inflammatory conditions, such as asthma, COPD, atopic dermatitis, multiple sclerosis, and rheumatoid arthritis. The development of most of these compounds, however, has been discontinued because of narrow therapeutic windows. A major reason for their poor clinical results is the consequence of dosing limitation caused by side effects such as nausea and emesis. The PDE4 inhibitors explored in clinical trials have been mostly for asthma, likely because of the high prevalence and increasing morbidity of the disease. However, no compounds have yet reached the market as asthma treatments. Nevertheless, the first orally active PDE4 inhibitor roflumilast was approved in June 2010 by the European Medicines Agency Committee for severe COPD associated with chronic bronchitis in adult patients. In March 2011, the United States Food and Drug Administration approved the drug for reducing COPD exacerbations. ${ }^{(70,71)}$ Clinical studies have shown that roflumilast improves lung function and reduces the frequency of COPD exacerbations in patients with symptoms of chronic bronchitis. ${ }^{(71-74)}$ Although the side effects were generally mild to moderate, nausea, diarrhea, headache, and weight loss are noted with roflumilast. ${ }^{(70)}$

In view of the side effect profile of second-generation PDE4 inhibitors, new strategies for the design of active and nonemetic compounds have been attempted to hopefully overcome the problems and to improve therapeutic ratios. It has been hypothesized that the side effects of the PDE4 inhibitors are probably a result of their nonselectivity to all four PDE4 subtypes, and thus generation of new PDE4 inhibitors with subtype selectivity may provide clinical benefits by maintaining therapeutic efficacy while decreasing the side effects. ${ }^{(75)}$ This notion is supported by a series of studies where PDE4 gene-targeted mice were used to define the function of individual PDE4 subtypes. ${ }^{(76)}$ For example, the data have shown that ablation of PDE4B, but not PDE4A or PDE4D, significantly suppresses LPS-induced tumor necrosis factor (TNF)- $\alpha$ production in circulating monocytes and peritoneal macrophages. ${ }^{(44,45)}$ In addition, in a murine model of allergic asthma, Th2 cell functions including proliferation and cytokine production, were also disrupted in mice deficient in PDE4B, but not PDE4A or PDE4D. ${ }^{(77,78)}$ In a separate study, reversing $\alpha_{2}$-adrenoceptor-mediated anesthesia, a behavioral correlate of emesis in nonvomiting species such as rodents, was evaluated in xylazine/ketamine-treated mice and the results indicated that inhibition of PDE4D but not PDE4B may be responsible for the emetic effects of non-selective PDE4 inhibitors. ${ }^{(79)}$ Taken together, these findings in PDE4 knockout mice suggest that an inhibitor with PDE4B selectivity should retain many beneficial antiinflammatory effects without the emetic effects.

In spite of the significant challenges of synthe- 
sizing PDE4 subtype-selective inhibitors due to the highly conserved catalytic domain of PDE4 isozymes, generation of inhibitors with PDE4 subtype selectivity has recently been described. ${ }^{\left({ }^{(00,81)}\right.} \mathrm{A}$ series of potent PDE4B inhibitors with more than 100-fold selectivity over PDE4D have been synthesized from lead 2-arylpyrimidine derivatives. ${ }^{(80)}$ Biological evaluation of a selective PDE4B inhibitor revealed its potent antiinflammatory effects in vitro and in vivo. Investigation in ferrets also showed a significantly less emesis with the compound compared with the non-selective PDE4 inhibitor cilomilast. ${ }^{(80)}$ In a separate report, small-molecule allosteric modulators of PDE4D have been generated using a nontraditional approach. ${ }^{(81)}$ These modulators do not completely inhibit enzyme activity, yet show potent cognition enhancement in animal models. Interestingly, the results from the rodent model of a behavioral correlate of emesis indicated that PDE4D allosteric modulators have reduced potential to cause emesis whereas PDE4D full inhibitors are highly emetic. ${ }^{(81)}$ The reason for this different emetic effect is probably because PDE4D allosteric modulators have less effect on cAMP levels, because of their lower potency of PDE4 inhibition compared with full inhibitors of PDE4, and thus are able to better maintain cAMP signaling spatially and temporally while reducing target-based toxicity. ${ }^{(81)}$

To avoid the problem of systemic side effects caused by oral administration, development of PDE4 inhibitors with alternative routes of delivery has been reported. ${ }^{(82)}$ In general, when delivered by inhalation, the drug may have reduced systemic exposure and focused delivery to lung tissues, thus minimizing the potential of systemic side effects. GSK256066 is an inhaled PDE4 inhibitor which shows a protective effect on both early and late asthmatic responses to inhaled allergen in atopic asthmatics. ${ }^{(82)}$ The drug was well tolerated with low systemic exposure, but larger studies are needed to establish the safety profile. Topical application of PDE4 inhibitors is another potential means to minimize systemic side effects. Benzylamine-substituted phthalazinones have recently been developed as potent topically active PDE4 inhibitors, and have shown anti-inflammatory effects in a mouse model of dermatitis. ${ }^{(83)}$ Additional studies are required to evaluate the therapeutic index of the compounds. Although the majority of orally administered PDE4 inhibitors face the issue of side effects, a number of oral compounds currently in development, such as apremilast for psoriasis ${ }^{(84)}$ and the PDE4D allosteric modulators as described above, ${ }^{(81)}$ are reported to be less emetic and have wider therapeutic ratios. The molecular mechanism of this tolerability has not been reported.

\section{Effects of PDE4 inhibition in leukocytes}

Cyclic AMP-elevating agents including PDE4 inhibitors are known to suppress a myriad of inflammatory responses in most immune and inflammatory cells. These effector responses include proliferation, chemotaxis, phagocytosis, and release of proinflammatory mediators such as lipid mediators, reactive oxygen species (ROS), hydrolytic enzymes, cytokines and chemokines. ${ }^{(2,40,85)}$ The antiinflammatory effects derived from PDE4 inhibition or ablation in leukocytes are briefly reviewed below.

\section{Monocytes and macrophages}

Among the immune cells, circulating monocytes and tissue macrophages are key players in the innate immune responses. They are a major source of TNF$\alpha$, a proinflammatory cytokine that orchestrates the complex processes involved in immunity as well as inflammatory disease states, such as rheumatoid arthritis, Crohn's disease, and septic shock. ${ }^{(86-89)}$ Through activation of toll-like receptor (TLR) signaling, the endotoxin LPS stimulates TNF- $\alpha$ production in monocytes and macrophages. The TNF- $\alpha$ release induced by LPS is markedly inhibited by PDE4 inhibitors in blood monocytes, ${ }^{(2,44,75)}$ whereas the inhibition is less evident in tissue macrophages. ${ }^{(44,45)}$ This discrepancy may be explained by the different PDE isozyme activity profiles in the two cell types, with monocytes containing predominantly PDE4 while PDEs 1,3 and 4 are major isoforms in alveolar macrophages. ${ }^{(90)}$ Despite the simultaneous expression of the three PDE4 genes (PDE4A, PDE4B, and PDE4D), LPS stimulation of TLR selectively induces PDE4B expression and activity in circulating monocytes ${ }^{(43,44)}$ and peritoneal macrophages. ${ }^{(45)}$ Functionally, ablation of PDE4B, but not PDE4A or PDE4D significantly reduces LPS-induced TNF- $\alpha$ release in these cells. In addition, the PDE4 inhibitors have no additional inhibitory effect on the TNF- $\alpha$ release in PDE4B-deficient macrophages while significantly suppressing the response in PDE4A- and PDE4D-null cells. These 
data demonstrate that the pharmacological effects of PDE4 inhibitors on macrophage TNF- $\alpha$ production are mediated exclusively through inhibition of PDE4B. ${ }^{(44,45)}$

cAMP regulates multiple cellular processes through activation of at least three distinct signaling effectors, including PKA, exchange proteins directly activated by cAMP (Epac), and cyclic nucleotidegated ion channels. A variety of inflammatory responses inhibited by cAMP are mediated by PKA or Epac. For example, activation of PKA, but not Epac, suppresses LPS-induced TNF- $\alpha$ production and ionophore A23187-stimulated leukotriene B4 (LTB4) production in alveolar and peritoneal macropages ${ }^{(45,91)}$ By contrast, activation of Epac, but not PKA, suppresses Fc $\gamma$ R-mediated phagocytosis and LPS-induced interferon (IFN)- $\beta$ production in macrophages. ${ }^{(91,92)}$ Interestingly, in human monocytederived macrophages, cAMP has been demonstrated to induce, rather than decrease, the expression and secretion of several proinflammatory chemokines such as CXCL-7, CXCL-5, and CCL-2. This effect is mediated by activation of Epac but not PKA. ${ }^{(93)}$

\section{T lymphocytes}

In T lymphocytes, PDE4 inhibitors are shown to attenuate anti-CD3/CD28-, mitogen-, and specific antigen-stimulated T-cell activation, proliferation, and cytokine release such as interleukin (IL)-2, IL-5, and IFN- $\gamma \cdot{ }^{(2,42,54)}$ Some of these inhibitory effects have been demonstrated to be prevented by PKA inhibitors. ${ }^{(94)}$ PDE3 inhibitors have little or no effect on these responses, but they can enhance the effects of PDE4 inhibitors. ${ }^{(95-98)}$ Additionally, induction of PDE7 is demonstrated to be necessary for T cell activation and IL-2 production. ${ }^{(99)}$ To define the functional role of each PDE4 subtype in $\mathrm{CD}^{+} \mathrm{T}$ cells, Peter and colleagues employed PDE4 subtype-specific siRNAs in human anti-CD3/CD28-stimulated T cells. The results indicate that PDE4B and PDE4D are involved in modulating early or "short-term" responses, such as IL-2 release, and PDE4D is a predominant subtype conducting "long-term" responses, such as IFN- $\gamma$ and IL-5 release and proliferation. ${ }^{(42)}$

$\mathrm{CD} 4^{+}$helper $\mathrm{T}\left(\mathrm{T}_{\mathrm{H}}\right)$ cells are classified into different functional subsets depending on their cytokine profiles. $\mathrm{T}_{\mathrm{H}} 1$ cells produce predominantly IFN- $\gamma$ and lymphotoxin and are pivotal in macrophage activation. $\mathrm{T}_{\mathrm{H}} 2$ cells secrete predominantly IL-4, IL-5, and
IL-13, and are important for immunoglobulin (Ig) E production as well as eosinophil differentiation and activation. Exaggerated $\mathrm{T}_{\mathrm{H}} 1$ responses may lead to autoimmune diseases, such as type 1 diabetes, rheumatoid arthritis, and multiple sclerosis, whereas $\mathrm{T}_{\mathrm{H}} 2$ cells are associated with allergic conditions such as asthma and anaphylaxis. ${ }^{(100-102)}$ Reports on the effects of PDE4 inhibitors on proliferation and cytokine release in these cells are somewhat irreconcilable. Essayan and colleagues demonstrated that the proliferation of both $\mathrm{T}_{\mathrm{H}} 1$ and $\mathrm{T}_{\mathrm{H}} 2$ clonal cells are inhibited by rolipram, with $\mathrm{T}_{\mathrm{H}} 2$ cells being more sensitive to PDE4 inhibition. ${ }^{(98)}$ PDE4 inhibitors are also shown to block the release of both $\mathrm{T}_{\mathrm{H}} 1$ and $\mathrm{T}_{\mathrm{H}} 2$ cytokines. ${ }^{(98,103)}$ Contrarily, using $\mathrm{T}_{\mathrm{H}} 1$ and $\mathrm{T}_{\mathrm{H}} 2$ cells derived from ovalbumin-specific $\mathrm{T}$-cell receptor transgenic mice, Claveau et al. reported that PDE4 inhibitors significantly inhibited $\mathrm{T}_{\mathrm{H}} 1$-mediated IFN- $\gamma$ production, but had no significant effect on $\mathrm{T}_{\mathrm{H}} 2$ mediated IL-4 or IL-13 production. $^{(104)}$ On the other hand, studies of PDE4 knockout mice in a murine model of asthma revealed that airway-draining lymph node cells deficient in PDE4B, but not PDE4A or PDE4D, produced a marked reduction in T-cell proliferation and $\mathrm{T}_{\mathrm{H}} 2$ cytokine production, including IL-4, IL-5, and IL-13. ${ }^{(77,78)}$ Conversely, release of the $T_{H} 1$ cytokine IFN- $\gamma$ was not affected in PDE4B null cells. ${ }^{(78)}$

The subset $\mathrm{T}_{\mathrm{H}} 17$ cells are important in host defense against specific extracellular pathogens, and are also thought to be involved in the pathogenesis of autoimmune diseases. ${ }^{(105)}$ These cells produce IL-17A and IL-17F, which upon ligation to their receptors induce secretion of several proinflammatory cytokines and chemokines to promote neutrophil recruitment, thus leading to tissue inflammation. A recent study demonstrated that PDE4 inhibitors also profoundly attenuate IL-17 production in antiCD3/CD28-stimulated peripheral blood mononuclear cells, purified $\mathrm{CD}^{+} \mathrm{T}$ cells, and memory $\mathrm{T}_{\mathrm{H}} 17$ cells. ${ }^{(106)}$

\section{Neutrophils}

Neutrophils are a type of phagocyte that circulates in the blood awaiting the call from an infected site to become activated and recruited. Upon stimulation by inflammatory mediators such as the bacterial component $\mathrm{N}$-formyl-methionyl-leucyl-phenylalanine (fMLP), the C5 complement fragment C5a, and 
the chemokine IL- 8 , these cells are induced to express adhesion molecules, infiltrate into the inflammatory site, and subsequently undergo phagocytosis and produce inflammatory mediators, such as ROS, proteases, and $\mathrm{LTB}_{4}$. Consistent with the predominant PDE4 expression in these cells, PDE4 inhibitors suppress a variety of neutrophil responses, including fMLP-induced generation of superoxide anion and $\mathrm{LTB}_{4},{ }^{(107-109)}$ degranulation, ${ }^{(110,111)}$ and expression of adhesion molecules. ${ }^{(111-113)}$ Inhibition of PDE4 also reduces the ability of neutrophils to phagocytose zymosan particles. ${ }^{(114)}$ To define the role of individual PDE4 subtypes in neutrophils, a study in an animal model of airway neutrophilia, a characteristic feature of COPD, was conducted in PDE4-deficient mice. ${ }^{(115)}$ The data showed that ablation of PDE4D or PDE4B, but not PDE4A, had profound effects on neutrophil functions. These include a significant reduction in neutrophil recruitment to the lung of PDE4B and PDE4D null mice after exposure to inhaled LPS, and an associated decrease in the expression of the adhesion molecule $\beta_{2}$-integrin (CD18) in the neutrophils of these mice. Chemotaxis in response to IL- 8 or macrophage inflammatory protein (MIP)-2 is also attenuated in the splenic neutrophils of PDE4B and PDE4D null mice. ${ }^{(115)}$

\section{Eosinophils}

Eosinophils are responsible for defending against helminths, worms, and other intestinal parasites. Along with activated mast cells, they also participate in the pathogenesis of allergic conditions such as asthma. Upon stimulation by cytokines such as IL-5, IL-3 and granulocyte macrophage colonystimulating factor or inflammatory factors such as fMLP, C5a, and platelet-activating factor (PAF), eosinophils release a plethora of toxic substances and proinflammatory mediators, including ROS, cationic granule proteins, leukotrienes, and various cytokines, which are thought to cause airway damage in asthmatics. ${ }^{(54)}$ Some of these responses, such as fMLPand C5a-induced ROS formation ${ }^{(109)}$ as well as C5aand PAF-stimulated leukotriene $\mathrm{C} 4\left(\mathrm{LTC}_{4}\right)$ production, ${ }^{(116)}$ have been shown to be potently inhibited by PDE4 inhibitors. Moreover, inhibition of PDE4 also suppresses the expression of adhesion molecules and consequently decreases the chemotaxis of human eosinophils. ${ }^{(116,117)}$ An earlier study indicated that PDE4 inhibitors are able to inhibit IL-5-induced sur- vival of human eosinophils. ${ }^{(118)}$ However, a recent report suggests that spontaneous eosinophil apoptosis is delayed by rolipram in vitro, and combining a PDE4 inhibitor with a $\beta_{2}$-agonist produces a further delay in apoptosis. ${ }^{(119)}$

\section{Mast cells and basophils}

Mast cells are resident in tissues throughout the body, particularly in the connective tissues underlying the mucosa of the respiratory and gastrointestinal tracts as well as the dermis of the skin. Mast cells and circulating basophils are important in mediating allergic disorders such as asthma and anaphylaxis. These cells become activated when the IgE molecules bound to high affinity IgE receptors FceRI on their cell surface are cross-linked to antigens. This results in a rapid release of granule contents such as histamine and other inflammatory mediators. Limited information is available on how PDE4 inhibitors regulate inflammatory responses in mast cells. In a series of studies, Peachell and colleagues showed that PDE4 inhibitors can attenuate anti-IgEinduced release of histamine and $\mathrm{LTC}_{4}$ from human basophils, ${ }^{(120,121)}$ but are ineffective at inhibiting these responses in human lung mast cells. ${ }^{(121)}$ Additionally, the IgE- and IL-3-mediated release of histamine, as well as IL-4 and IL-13, have also been shown to be inhibited by PDE4 inhibitors in basophils. ${ }^{(122)}$

\section{B lymphocytes}

Upon antigen recognition, B lymphocytes are activated, proliferate, and differentiate into Ig-producing plasma cells, which represent the key mediator of humoral immunity. The isotype class switch of $\mathrm{B}$ cells to IgE production is known to be crucial in the development of many allergic conditions including asthma. Th2 cytokines, IL-4 in particular, induce IgE production in B cells. ${ }^{(123)}$ Mice deficient in IL-4 fail to produce measurable levels of allergen-specific IgE. ${ }^{(124)}$ Several cAMP-elevating agents, such as PDE4 inhibitors, $\beta_{2}$-agonists, cAMP analogs, and Eseries prostaglandins, are shown to enhance the IL-4directed IgE production. ${ }^{(125)}$ A separate report also indicates that B-cell proliferation induced by LPS plus IL-4 is augmented by rolipram; ${ }^{(126)}$ however, this effect is not mimicked by PGE2 or forskolin. Interestingly, Paul-Eugene et al. have shown that IL4-induced IgE production can be potentiated by cAMP only when B cells are stimulated at a subopti- 
mal concentration of IL-4. ${ }^{(127)}$ These data are consistent with the recent findings that ablation of PDE4B, and therefore a condition of increased cAMP, results in normal IgE production in spite of low IL-4 in PDE4B null mice. ${ }^{(78)}$

\section{Dendritic cells}

Dendritic cells (DC) are antigen presenting cells whose major function is to prime naive $\mathrm{T}$ cells and trigger T-cell responses. Human monocyte-derived DCs express predominantly PDE4, with PDE4A being the most abundant mRNA. ${ }^{(128)}$ In immature DC, LPS- or CD40L-induced TNF- $\alpha$ and IL-12p70 production is reduced by PDE4 inhibitors. DCs matured in the presence of PDE4 inhibitors are still able to stimulate $\mathrm{T}$ cells; however, they show an increased expression of C-X-C chemokine receptor 4 and reduced TNF- $\alpha$ and IL-12p70 production in response to CD40L. Moreover, when these matured DCs are used to stimulate naive T cells, a reduction in IFN- $\gamma$ producing $\left(\mathrm{T}_{\mathrm{H}} 1\right)$ cells is observed. ${ }^{(128)}$ This result is in contrast with the findings reported in mice deficient in PDE4B or PDE4A, where a normal IFN- $\gamma$ response is produced in response to allergen stimulation. ${ }^{(78)}$ A separate study using murine bone marrowderived dendritic cells (BMDC) has shown that analogs of the lipid mediator prostaglandin $\mathrm{I}_{2}$, such as iloprost, cicaprost, and treprostinil, suppress the LPS-induced production of several proinflammatory cytokines and chemokines, such as IL-12, TNF- $\alpha$, IL- $1 \alpha$, IL-6, MIP-1 $\alpha$, and monocyte chemotactic protein-1, while increasing the antiinflammatory cytokine IL-10 production in these cells. This modulatory effect is associated with an upregulation of intracellular cAMP and downregulation of nuclear factor kappa B activity. ${ }^{(129)}$ Moreover, the regulation of cytokine and chemokine production by cAMP is mediated by both Epac-1 and PKA activation in BMDC. ${ }^{(130)}$ Little is known about how PDE4 inhibitors influence inflammatory responses in these cells.

\section{Conclusion}

Almost two decades have passed since targeting PDE4 became a focus in the development of novel therapeutics for pulmonary inflammatory diseases. The recent approval of roflumilast as a drug for COPD therapy provides proof that the PDE4 isozyme family can be a therapeutic target.
Nevertheless, this second-generation PDE4 inhibitor is still not without side effects. Several strategies have been proposed to minimize this problem, such as designing inhibitors as inhaled drugs or topically applied agents, as well as improving subtype selectivity. The development of PDE4 inhibitors with PDE4B selectivity has been considered a promising approach because much evidence demonstrates that ablation or inhibition of PDE4B produces a broad spectrum of antiinflammatory effects while minimizing unwanted side effects. ${ }^{(76,80)}$ Nevertheless, the impact of PDE4B-selective inhibitors on inflammatory diseases awaits further clinical trials. Several PDE4B and PDE4D selective inhibitors have been designed and synthesized, and their effects on inflammation are under investigation. The development of additional PDE4 subtype-selective inhibitors based on their detailed crystal structures is also underway.

\section{Acknowledgements}

We thank Dr. Jyh-I Lu for editorial assistance on this review. This work was supported by the National Science Council (NSC98-2320-B-008-001 to S.-L. C. Jin, Taiwan) and the Cathy General Hospital National Central University Joint Research Foundation (99CGH-NCU-A1 to S.-L. C Jin and S. C. Lin).

\section{REFERENCES}

1. Sutherland EW, Rall TW. Fractionation and characterization of a cyclic adenine ribonucleotide formed by tissue particles. J Biol Chem 1958;232:1077-91.

2. Torphy TJ. Phosphodiesterase isozymes: molecular targets for novel antiasthma agents. Am J Respir Crit Care Med 1998;157:351-70.

3. Beavo J, Francis S, Houslay M. Cyclic Nucleotide Phosphodiesterases in Health and Disease. Boca Raton, FL: CRC Press, 2007:1-713.

4. Uretsky BF, Generalovich T, Reddy PS, Spangenberg RB, Follansbee WP. The acute hemodynamic effects of a new agent, MDL 17,043, in the treatment of congestive heart failure. Circulation 1983;67:823-8.

5. Feldman AM, Bristow MR, Parmley WW, Carson PE, Pepine CJ, Gilbert EM, Strobeck JE, Hendrix GH, Rowers ER, Bain RP, White BG. Effects of vesnarinone on morbidity and mortality in patients with heart failure. Vesnarinone Study Group. N Engl J Med 1993;329:14955.

6. Jaski BE, Fifer MA, Wright RF, Braunwald E, Colucci 
WS. Positive inotropic and vasodilator actions of milrinone in patients with severe congestive heart failure. Dose-response relationships and comparison to nitroprusside. J Clin Invest 1985;75:643-9.

7. Dawson DL, Cutler BS, Meissner MH, Strandness DE Jr. Cilostazol has beneficial effects in treatment of intermittent claudication: results from a multicenter, randomized, prospective, double-blind trial. Circulation 1998;98:67886.

8. Money SR, Herd JA, Isaacsohn JL, Davidson M, Cutler B, Heckman J, Forbes WP. Effect of cilostazol on walking distances in patients with intermittent claudication caused by peripheral vascular disease. J Vasc Surg 1998;27:267-74; discussion 74-5.

9. Boolell M, Gepi-Attee S, Gingell JC, Allen MJ. Sildenafil, a novel effective oral therapy for male erectile dysfunction. Br J Urol 1996;78:257-61.

10. Boolell M, Allen MJ, Ballard SA, Gepi-Attee S, Muirhead GJ, Naylor AM, Osterloh IH, Gingell C. Sildenafil: an orally active type 5 cyclic GMP-specific phosphodiesterase inhibitor for the treatment of penile erectile dysfunction. Int J Impot Res 1996;8:47-52.

11. Diamant Z, Spina D. PDE4-inhibitors: A novel, targeted therapy for obstructive airways disease. Pulm Pharmacol Ther 2011;24:353-60.

12. Hatzelmann A, Morcillo EJ, Lungarella G, Adnot S, Sanjar S, Beume R, Schudt C, Tenor H. The preclinical pharmacology of roflumilast--a selective, oral phosphodiesterase 4 inhibitor in development for chronic obstructive pulmonary disease. Pulm Pharmacol Ther 2010;23: 235-56.

13. Page CP, Spina D. Phosphodiesterase inhibitors in the treatment of inflammatory diseases. Handb Exp Pharmacol 2011;204:391-414.

14. Zhang HT. Cyclic AMP-specific phosphodiesterase-4 as a target for the development of antidepressant drugs. Curr Pharm Des 2009;15:1688-98.

15. Siuciak JA. The role of phosphodiesterases in schizophrenia: therapeutic implications. CNS Drugs 2008;22: 983-93.

16. Millar JK, Pickard BS, Mackie S, James R, Christie S, Buchanan SR, Malloy MP, Chubb JE, Huston E, Baillie GS, Thomson PA, Hill EV, Brandon NJ, Rain JC, Camargo M, Whiting PJ, Houslay MD, Blackwood DH, Muir WJ, Porteous DJ. DISC1 and PDE4B are interacting genetic factors in schizophrenia that regulate cAMP signaling. Science 2005;310:1187-91.

17. Essayan DM. Cyclic nucleotide phosphodiesterases. J Allergy Clin Immunol 2001;108:671-80.

18. Francis SH, Turko IV, Corbin JD. Cyclic nucleotide phosphodiesterases: relating structure and function. Prog Nucleic Acid Res Mol Biol 2001;65:1-52.

19. Mehats C, Andersen CB, Filopanti M, Jin SL, Conti M. Cyclic nucleotide phosphodiesterases and their role in endocrine cell signaling. Trends Endocrinol Metab
2002;13:29-35.

20. Beavo JA, Houslay MD, Francis SH. Cyclic nucleotide phosphodiesterase superfamily. In: Beavo JA, Francis SH, Houslay MD, eds. Cyclic Nucleotide Phosphodiesterases in Health and Disease. Boca Raton, FL: CRC Press, 2007:3-17.

21. Conti M, Jin SL. The molecular biology of cyclic nucleotide phosphodiesterases. Prog Nucleic Acid Res Mol Biol 1999;63:1-38.

22. Conti M, Beavo J. Biochemistry and physiology of cyclic nucleotide phosphodiesterases: essential components in cyclic nucleotide signaling. Annu Rev Biochem 2007;76: 481-511.

23. Bolger GB. Phosphodiesterase isoforms - An annotated list. In: Beavo JA, Francis SH, Houslay MD, eds. Cyclic Nucleotide Phosphodiesterases in Health and Disease. Boca Raton, FL: CRC Press, 2007:19-31.

24. Kovala T, Sanwal BD, Ball EH. Recombinant expression of a type IV, cAMP-specific phosphodiesterase: characterization and structure-function studies of deletion mutants. Biochemistry 1997;36:2968-76.

25. Lenhard JM, Kassel DB, Rocque WJ, Hamacher L, Holmes WD, Patel I, C Hoffman, M Luther. Phosphorylation of a cAMP-specific phosphodiesterase (HSPDE4B2B) by mitogen-activated protein kinase. Biochem J 1996;316:751-8.

26. Hoffmann R, Baillie GS, MacKenzie SJ, Yarwood SJ, Houslay MD. The MAP kinase ERK2 inhibits the cyclic AMP-specific phosphodiesterase HSPDE4D3 by phosphorylating it at Ser579. EMBO J 1999;18:893-903.

27. Anant JS, Ong OC, Xie HY, Clarke S, O'Brien PJ, Fung BK. In vivo differential prenylation of retinal cyclic GMP phosphodiesterase catalytic subunits. J Biol Chem 1992;267:687-90.

28. Houslay MD. Underpinning compartmentalised cAMP signalling through targeted cAMP breakdown. Trends Biochem Sci 2010;35:91-100.

29. Houslay MD. PDE4 cAMP-specific phosphodiesterases. Prog Nucleic Acid Res Mol Biol 2001;69:249-315.

30. Jin SL, Swinnen JV, Conti M. Characterization of the structure of a low Km, rolipram- sensitive cAMP phosphodiesterase. Mapping of the catalytic domain. J Biol Chem 1992;267:18929-39.

31. Jacobitz S, McLaughlin MM, Livi GP, Burman M, Torphy TJ. Mapping the functional domains of human recombinant phosphodiesterase 4A: structural requirements for catalytic activity and rolipram binding. Mol Pharmacol 1996;50:891-9.

32. Bolger G, Michaeli T, Martins T, St John T, Steiner B, Rodgers L, Riggs M, Wigler M, Ferguson K. A family of human phosphodiesterases homologous to the dunce learning and memory gene product of Drosophila melanogaster are potential targets for antidepressant drugs. Mol Cell Biol 1993;13:6558-71.

33. Houslay MD, Schafer P, Zhang KY. Keynote review: 
phosphodiesterase-4 as a therapeutic target. Drug Discov Today 2005;10:1503-19.

34. Lim J, Pahlke G, Conti M. Activation of the cAMP-specific phosphodiesterase PDE4D3 by phosphorylation. Identification and function of an inhibitory domain. J Biol Chem 1999;274:19677-85.

35. Sette C, Conti M. Phosphorylation and activation of a cAMP-specific phosphodiesterase by the cAMP-dependent protein kinase. Involvement of serine 54 in the enzyme activation. J Biol Chem 1996;271:16526-34.

36. MacKenzie SJ, Baillie GS, McPhee I, MacKenzie C, Seamons R, McSorley T, Millen J, Beard MB, van Heeke G, Houslay MD. Long PDE4 cAMP specific phosphodiesterases are activated by protein kinase A-mediated phosphorylation of a single serine residue in Upstream Conserved Region 1 (UCR1). Br J Pharmacol 2002;136: 421-33.

37. Beard MB, Olsen AE, Jones RE, Erdogan S, Houslay MD, Bolger GB. UCR1 and UCR2 domains unique to the cAMP-specific phosphodiesterase family form a discrete module via electrostatic interactions. J Biol Chem 2000;275:10349-58.

38. Richter W, Conti M. Dimerization of the type 4 cAMPspecific phosphodiesterases is mediated by the upstream conserved regions (UCRs). J Biol Chem 2002;12:12.

39. Richter W, Conti M. The oligomerization state determines regulatory properties and inhibitor sensitivity of type 4 cAMP-specific phosphodiesterases. J Biol Chem 2004;279:30338-48.

40. Press NJ, Banner KH. PDE4 inhibitors - a review of the current field. Prog Med Chem 2009;47:37-74.

41. Seybold J, Newton R, Wright L, Finney PA, Suttorp N, Barnes PJ, Adcock IM, Giembycz MA. Induction of phosphodiesterases 3B, 4A4, 4D1, 4D2, and 4D3 in Jurkat T-cells and in human peripheral blood T-lymphocytes by 8-bromo-cAMP and Gs-coupled receptor agonists. Potential role in beta2-adrenoreceptor desensitization. J Biol Chem 1998;273:20575-88.

42. Peter D, Jin SL, Conti M, Hatzelmann A, Zitt C. Differential expression and function of phosphodiesterase 4 (PDE4) subtypes in human primary CD4+ T cells: predominant role of PDE4D. J Immunol 2007;178: 4820-31.

43. Ma D, Wu P, Egan RW, Billah MM, Wang P. Phosphodiesterase 4B gene transcription is activated by lipopolysaccharide and inhibited by interleukin-10 in human monocytes. Mol Pharmacol 1999;55:50-7.

44. Jin SL, Conti M. Induction of the cyclic nucleotide phosphodiesterase PDE4B is essential for LPS-activated TNF-alpha responses. Proc Natl Acad Sci USA 2002;99: 7628-33.

45. Jin SL, Lan L, Zoudilova M, Conti M. Specific role of phosphodiesterase 4B in lipopolysaccharide-induced signaling in mouse macrophages. J Immunol 2005;175: 1523-31.
46. Barber R, Baillie GS, Bergmann R, Shepherd MC, Sepper R, Houslay MD, Heeke GV. Differential expression of PDE4 cAMP phosphodiesterase isoforms in inflammatory cells of smokers with COPD, smokers without COPD, and nonsmokers. Am J Physiol Lung Cell Mol Physiol 2004;287:L332-43.

47. Banner KH, Trevethick MA. PDE4 inhibition: a novel approach for the treatment of inflammatory bowel disease. Trends Pharmacol Sci 2004;25:430-6.

48. Keshavarzian A, Mutlu E, Guzman JP, Forsyth C, Banan A. Phosphodiesterase 4 inhibitors and inflammatory bowel disease: emerging therapies in inflammatory bowel disease. Expert Opin Investig Drugs 2007;16: 1489-506.

49. Baumer W, Hoppmann J, Rundfeldt C, Kietzmann M. Highly selective phosphodiesterase 4 inhibitors for the treatment of allergic skin diseases and psoriasis. Inflamm Allergy Drug Targets 2007;6:17-26.

50. Nazarian R, Weinberg JM. AN-2728, a PDE4 inhibitor for the potential topical treatment of psoriasis and atopic dermatitis. Curr Opin Investig Drugs 2009;10:1236-42.

51. Millar JK, Mackie S, Clapcote SJ, Murdoch H, Pickard BS, Christie S, Muir WJ, Blackwood DH, Roder JC, Houslay MD, Porteous DJ. Disrupted in schizophrenia 1 and phosphodiesterase 4B: towards an understanding of psychiatric illness. J Physiol 2007;584:401-5.

52. Ghavami A, Hirst WD, Novak TJ. Selective phosphodiesterase (PDE)-4 inhibitors: a novel approach to treating memory deficit? Drugs R D 2006;7:63-71.

53. Rose GM, Hopper A, De Vivo M, Tehim A. Phosphodiesterase inhibitors for cognitive enhancement. Curr Pharm Des 2005;11:3329-34.

54. Souness JE, Aldous D, Sargent C. Immunosuppressive and anti-inflammatory effects of cyclic AMP phosphodiesterase (PDE) type 4 inhibitors. Immunopharmacology 2000;47:127-62.

55. Lipworth BJ. Phosphodiesterase-4 inhibitors for asthma and chronic obstructive pulmonary disease. Lancet 2005;365:167-75.

56. Spina D. PDE4 inhibitors: current status. Br J Pharmacol 2008;155:308-15.

57. Schultze-Werninghaus G, Meier-Sydow J. The clinical and pharmacological history of theophylline: first report on the bronchospasmolytic action in man by S. R. Hirsch in Frankfurt (Main) 1922. Clin Allergy 1982;12:211-5.

58. Banner KH, Page CP. Theophylline and selective phosphodiesterase inhibitors as anti-inflammatory drugs in the treatment of bronchial asthma. Eur Respir J 1995;8: 996-1000.

59. Diamant Z, Boot JD, Virchow JC. Summing up 100 years of asthma. Respir Med 2007;101:378-88.

60. Daly JW, Jacobson KA, Ukena D. Adenosine receptors: development of selective agonists and antagonists. Prog Clin Biol Res 1987;230:41-63.

61. Fredholm BB, Persson CG. Xanthine derivatives as 
adenosine receptor antagonists. Eur J Pharmacol 1982;81:673-6.

62. Ito K, Lim S, Caramori G, Cosio B, Chung KF, Adcock IM, Barnes PJ. A molecular mechanism of action of theophylline: Induction of histone deacetylase activity to decrease inflammatory gene expression. Proc Natl Acad Sci USA 2002;99:8921-6.

63. Polson JB, Krzanowski JJ, Goldman AL, Szentivanyi A. Inhibition of human pulmonary phosphodiesterase activity by therapeutic levels of theophylline. Clin Exp Pharmacol Physiol 1978;5:535-9.

64. To Y, Ito K, Kizawa Y, Failla M, Ito M, Kusama T, Elliott WM, Hogg JC, Adcock IM, Barnes PJ. Targeting phosphoinositide-3-kinase-delta with theophylline reverses corticosteroid insensitivity in chronic obstructive pulmonary disease. Am J Respir Crit Care Med 2010;182:897-904.

65. Barnes PJ. Targeting the epigenome in the treatment of asthma and chronic obstructive pulmonary disease. Proc Am Thorac Soc 2009;6:693-6.

66. Barnes PJ, Pauwels RA. Theophylline in the management of asthma: time for reappraisal? Eur Respir J 1994;7:579-91.

67. Barnes PJ. Current therapies for asthma. Promise and limitations. Chest 1997;111:17S-26S.

68. Giembycz MA. Phosphodiesterase 4 inhibitors and the treatment of asthma: where are we now and where do we go from here? Drugs 2000;59:193-212.

69. Giembycz MA. Life after PDE4: overcoming adverse events with dual-specificity phosphodiesterase inhibitors. Curr Opin Pharmacol 2005;5:238-44.

70. Giembycz MA, Field SK. Roflumilast: first phosphodiesterase 4 inhibitor approved for treatment of COPD. Drug Des Devel Ther 2010;4:147-58.

71. Rennard SI, Calverley PM, Goehring UM, Bredenbroker D, Martinez FJ. Reduction of exacerbations by the PDE4 inhibitor roflumilast--the importance of defining different subsets of patients with COPD. Respir Res 2011;12:18.

72. Rabe KF, Bateman ED, O'Donnell D, Witte S, Bredenbroker D, Bethke TD. Roflumilast--an oral antiinflammatory treatment for chronic obstructive pulmonary disease: a randomised controlled trial. Lancet 2005;366:563-71.

73. Calverley PM, Sanchez-Toril F, McIvor A, Teichmann P, Bredenbroeker D, Fabbri LM. Effect of 1-year treatment with roflumilast in severe chronic obstructive pulmonary disease. Am J Respir Crit Care Med 2007;176:154-61.

74. Calverley PM, Rabe KF, Goehring UM, Kristiansen S, Fabbri LM, Martinez FJ. Roflumilast in symptomatic chronic obstructive pulmonary disease: two randomised clinical trials. Lancet 2009;374:685-94.

75. Manning CD, Burman M, Christensen SB, Cieslinski LB, Essayan DM, Grous M, Torphy TJ, Barnette MS. Suppression of human inflammatory cell function by subtype-selective PDE4 inhibitors correlates with inhibi- tion of PDE4A and PDE4B. Br J Pharmacol 1999;128: 1393-8.

76. Jin SLC, Richter W, Conti M. Insights into the physiological functions of PDE4 from knockout mice. In: Beavo JA, Francis SH, Houslay MD, eds. Cyclic Nucleotide Phosphodiesterases in Health and Disease Boca Raton, FL: CRC Press, 2007:323-46.

77. Hansen G, Jin S, Umetsu DT, Conti M. Absence of muscarinic cholinergic airway responses in mice deficient in the cyclic nucleotide phosphodiesterase PDE4D. Proc Natl Acad Sci USA 2000;97:6751-6.

78. Jin SL, Goya S, Nakae S, Wang D, Bruss M, Hou C, Umetsu D, Conti M. Phosphodiesterase 4B is essential for $\mathrm{T}(\mathrm{H}) 2$-cell function and development of airway hyperresponsiveness in allergic asthma. J Allergy Clin Immunol 2010;126:1252-9 e12.

79. Robichaud A, Stamatiou PB, Jin SL, Lachance N, MacDonald D, Laliberte F, Liu S, Huang Z, Conti M, Chan CC. Deletion of phosphodiesterase 4D in mice shortens alpha2-adrenoceptor-mediated anesthesia; a behavioral correlate of emesis. J Clin Invest 2002;110: 1045-52.

80. Naganuma K, Omura A, Maekawara N, Saitoh M, Ohkawa N, Kubota T, Nagumo H, Kodama T, Takemura M, Ohtsuka Y, Nakamura J, Tsujita R, Kawasaki K, Yokoi H, Kawanishi M. Discovery of selective PDE4B inhibitors. Bioorg Med Chem Lett 2009;19:3174-6.

81. Burgin AB, Magnusson OT, Singh J, Witte P, Staker BL, Bjornsson JM, Thorsteinsdottir M, Hrafnsdottir S. Design of phosphodiesterase 4D (PDE4D) allosteric modulators for enhancing cognition with improved safety. Nat Biotechnol 2010;28:63-70.

82. Singh D, Petavy F, Macdonald AJ, Lazaar AL, O'Connor BJ. The inhaled phosphodiesterase 4 inhibitor GSK256066 reduces allergen challenge responses in asthma. Respir Res 2010;11:26.

83. Kagayama K, Morimoto T, Nagata S, Katoh F, Zhang X, Inoue N, Hashino A, Kageyama K, Shikaura J, Niwa T. Synthesis and biological evaluation of novel phthalazinone derivatives as topically active phosphodiesterase 4 inhibitors. Bioorg Med Chem 2009;17:6959-70.

84. Schafer PH, Parton A, Gandhi AK, Capone L, Adams M, Wu L, Bartlett JB, Loveland MA, Gilhar A, Cheung YF, Baillie GS, Houslay MD, Man HW, Muller GW, Stirling DI. Apremilast, a cAMP phosphodiesterase-4 inhibitor, demonstrates anti-inflammatory activity in vitro and in a model of psoriasis. Br J Pharmacol 2010;159:842-55.

85. Serezani CH, Ballinger MN, Aronoff DM, Peters-Golden M. Cyclic AMP: master regulator of innate immune cell function. Am J Respir Cell Mol Biol 2008;39:127-32.

86. Maini RN, Taylor PC. Anti-cytokine therapy for rheumatoid arthritis. Annu Rev Med 2000;51:207-29.

87. Bell S, Kamm MA. Antibodies to tumour necrosis factor alpha as treatment for Crohn's disease. Lancet 2000;355: 858-60. 
88. Beutler BA. The role of tumor necrosis factor in health and disease. J Rheumatol Suppl 1999;57:16-21.

89. Beutler B, Grau GE. Tumor necrosis factor in the pathogenesis of infectious diseases. Crit Care Med 1993;21: S423-35.

90. Tenor H, Hatzelmann A, Kupferschmidt R, Stanciu L, Djukanovic R, Schudt C, Wendel A, Church MK, Shute JK. Cyclic nucleotide phosphodiesterase isoenzyme activities in human alveolar macrophages. Clin Exp Allergy 1995;25:625-33.

91. Aronoff DM, Canetti C, Serezani CH, Luo M, PetersGolden M. Cutting edge: macrophage inhibition by cyclic AMP (cAMP): differential roles of protein kinase A and exchange protein directly activated by cAMP-1. J Immunol 2005;174:595-9.

92. Xu XJ, Reichner JS, Mastrofrancesco B, Henry WL Jr. Albina JE. Prostaglandin E2 suppresses lipopolysaccharide-stimulated IFN-beta production. J Immunol 2008;180:2125-31.

93. Hertz AL, Bender AT, Smith KC, Gilchrist M, Amieux PS, Aderem A, Beavo JA. Elevated cyclic AMP and PDE4 inhibition induce chemokine expression in human monocyte-derived macrophages. Proc Natl Acad Sci USA 2009;106:21978-83.

94. Jimenez JL, Punzon C, Navarro J, Munoz-Fernandez MA, Fresno M. Phosphodiesterase 4 inhibitors prevent cytokine secretion by $\mathrm{T}$ lymphocytes by inhibiting nuclear factor-kappaB and nuclear factor of activated $\mathrm{T}$ cells activation. J Pharmacol Exp Ther 2001;299:753-9.

95. Essayan DM, Huang SK, Undem BJ, Kagey-Sobotka A, Lichtenstein LM. Modulation of antigen- and mitogeninduced proliferative responses of peripheral blood mononuclear cells by nonselective and isozyme selective cyclic nucleotide phosphodiesterase inhibitors. J Immunol 1994;153:3408-16.

96. Essayan DM, Huang SK, Kagey-Sobotka A, Lichtenstein LM. Effects of nonselective and isozyme selective cyclic nucleotide phosphodiesterase inhibitors on antigeninduced cytokine gene expression in peripheral blood mononuclear cells. Am J Respir Cell Mol Biol 1995;13: 692-702.

97. Giembycz MA, Corrigan CJ, Seybold J, Newton R, Barnes PJ. Identification of cyclic AMP phosphodiesterases 3, 4 and 7 in human CD4+ and CD8+ T-lymphocytes: role in regulating proliferation and the biosynthesis of interleukin-2. Br J Pharmacol 1996;118:194558.

98. Essayan DM, Kagey-Sobotka A, Lichtenstein LM, Huang SK. Differential regulation of human antigen-specific Th1 and Th2 lymphocyte responses by isozyme selective cyclic nucleotide phosphodiesterase inhibitors. J Pharmacol Exp Ther 1997;282:505-12.

99. Li L, Yee C, Beavo JA. CD3- and CD28-dependent induction of PDE7 required for $\mathrm{T}$ cell activation. Science 1999;283:848-51.
100. Durrant DM, Metzger DW. Emerging roles of T helper subsets in the pathogenesis of asthma. Immunol Invest 2010;39:526-49.

101. Jager A, Kuchroo VK. Effector and regulatory T-cell subsets in autoimmunity and tissue inflammation. Scand J Immunol 2010;72:173-84.

102. Mucida D, Cheroutre H. The many face-lifts of CD4 T helper cells. Adv Immunol 2010;107:139-52.

103. Essayan DM, Kagey-Sobotka A, Lichtenstein LM, Huang SK. Regulation of interleukin-13 by type 4 cyclic nucleotide phosphodiesterase (PDE) inhibitors in allergen-specific human T lymphocyte clones. Biochem Pharmacol 1997;53:1055-60.

104. Claveau D, Chen SL, O'Keefe S, Zaller DM, Styhler A, Liu S, Huang Z, Nicholson DW, Mancini JA. Preferential inhibition of $\mathrm{T}$ helper 1, but not $\mathrm{T}$ helper 2, cytokines in vitro by L-826,141 [4-[2-(3,4-Bisdifluromethoxyphenyl)2-[4-(1,1,1,3,3,3-hexafluoro-2-hydroxy propan-2-yl)phenyl]-ethyl]3-methylpyridine-1-oxide], a potent and selective phosphodiesterase 4 inhibitor. J Pharmacol Exp Ther 2004;310:752-60.

105. Bettelli E, Korn T, Oukka M, Kuchroo VK. Induction and effector functions of $\mathrm{T}(\mathrm{H}) 17$ cells. Nature 2008;453: 1051-7.

106. Ma R, Yang BY, Wu CY. A selective phosphodiesterase 4 (PDE4) inhibitor Zl-n-91 suppresses IL-17 production by human memory Th17 cells. Int Immunopharmacol 2008;8:1408-17.

107. Nielson CP, Vestal RE, Sturm RJ, Heaslip R. Effects of selective phosphodiesterase inhibitors on the polymorphonuclear leukocyte respiratory burst. J Allergy Clin Immunol 1990;86:801-8.

108. Jacob C, Szilagyi C, Allen JM, Bertrand C, Lagente V. Role of PDE4 in superoxide anion generation through p44/42MAPK regulation: a cAMP and a PKA-independent mechanism. Br J Pharmacol 2004;143:257-68.

109. Hatzelmann A, Schudt C. Anti-inflammatory and immunomodulatory potential of the novel PDE4 inhibitor roflumilast in vitro. J Pharmacol Exp Ther 2001;297: 267-79.

110. Barnette MS, Christensen SB, Essayan DM, Grous M, Prabhakar U, Rush JA, Kagey-Sobotka A, Torphy TJ. SB 207499 (Ariflo), a potent and selective second-generation phosphodiesterase 4 inhibitor: in vitro anti-inflammatory actions. J Pharmacol Exp Ther 1998;284:420-6.

111. Jones NA, Boswell-Smith V, Lever R, Page CP. The effect of selective phosphodiesterase isoenzyme inhibition on neutrophil function in vitro. Pulm Pharmacol Ther 2005; 18:93-101.

112. Derian CK, Santulli RJ, Rao PE, Solomon HF, Barrett JA. Inhibition of chemotactic peptide-induced neutrophil adhesion to vascular endothelium by cAMP modulators. J Immunol 1995;154:308-17.

113. Sanz MJ, Cortijo J, Taha MA, Cerda-Nicolas M, Schatton E, Burgbacher B, Klar J, Tenor H, Schudt C, 
Issekutz AC, Hatzelmann A, Morcillo EJ. Roflumilast inhibits leukocyte-endothelial cell interactions, expression of adhesion molecules and microvascular permeability. Br J Pharmacol 2007;152:481-92.

114. Au BT, Teixeira MM, Collins PD, Williams TJ. Effect of PDE4 inhibitors on zymosan-induced IL-8 release from human neutrophils: synergism with prostanoids and salbutamol. Br J Pharmacol 1998;123:1260-6.

115. Ariga M, Neitzert B, Nakae S, Mottin G, Bertrand C, Pruniaux MP, Jin SL, Conti M. Nonredundant function of phosphodiesterases 4D and 4B in neutrophil recruitment to the site of inflammation. J Immunol 2004;173:7531-8.

116. Tenor H, Hatzelmann A, Church MK, Schudt C, Shute JK. Effects of theophylline and rolipram on leukotriene C4 (LTC4) synthesis and chemotaxis of human eosinophils from normal and atopic subjects. Br J Pharmacol 1996;118:1727-35.

117. Berends C, Dijkhuizen B, de Monchy JG, Dubois AE, Gerritsen J, Kauffman HF. Inhibition of PAF-induced expression of CD11b and shedding of L-selectin on human neutrophils and eosinophils by the type IV selective PDE inhibitor, rolipram. Eur Respir J 1997;10:10007.

118. Momose T, Okubo Y, Horie S, Suzuki J, Isobe M, Sekiguchi M. Effects of intracellular cyclic AMP modulators on human eosinophil survival, degranulation and CD11b expression. Int Arch Allergy Immunol 1998;117: 138-45.

119. Parkkonen J, Hasala H, Moilanen E, Giembycz MA, Kankaanranta H. Phosphodiesterase 4 inhibitors delay human eosinophil and neutrophil apoptosis in the absence and presence of salbutamol. Pulm Pharmacol Ther 2008;21:499-506.

120. Peachell PT, Undem BJ, Schleimer RP, MacGlashan DWJ, Lichtenstein LM, Cieslinski LB, Torphy TJ. Preliminary identification and role of phosphodiesterase isozymes in human basophils. J Immunol 1992;148: 2503-10.

121. Weston MC, Anderson N, Peachell PT. Effects of phosphodiesterase inhibitors on human lung mast cell and basophil function. Br J Pharmacol 1997;121:287-95.
122. Eskandari N, Wickramasinghe T, Peachell PT. Effects of phosphodiesterase inhibitors on interleukin-4 and interleukin-13 generation from human basophils. Br J Pharmacol 2004;142:1265-72.

123. Lebman DA, Coffman RL. Interleukin 4 causes isotype switching to IgE in T cell-stimulated clonal B cell cultures. J Exp Med 1988;168:853-62.

124. Hamelmann E, Takeda K, Haczku A, Cieslewicz G, Shultz L, Hamid Q, Xing Z, Gauldie J, Gelfand EW. Interleukin (IL)-5 but not immunoglobulin E reconstitutes airway inflammation and airway hyperresponsiveness in IL-4-deficient mice. Am J Respir Cell Mol Biol 2000;23:327-34.

125. Fedyk ER, Adawi A, Looney RJ, Phipps RP. Regulation of IgE and cytokine production by cAMP: implications for extrinsic asthma. Clin Immunol Immunopathol 1996;81:101-13.

126. Gantner F, Gotz C, Gekeler V, Schudt C, Wendel A, Hatzelmann A. Phosphodiesterase profile of human B lymphocytes from normal and atopic donors and the effects of PDE inhibition on B cell proliferation. Br J Pharmacol 1998;123:1031-8.

127. Paul-Eugene N, Pene J, Bousquet J, Dugas B. Role of cyclic nucleotides and nitric oxide in blood mononuclear cell IgE production stimulated by IL-4. Cytokine 1995;7:64-9.

128. Heystek HC, Thierry AC, Soulard P, Moulon C. Phosphodiesterase 4 inhibitors reduce human dendritic cell inflammatory cytokine production and Th1-polarizing capacity. Int Immunol 2003;15:827-35.

129. Zhou W, Hashimoto K, Goleniewska K, O’Neal JF, Ji S, Blackwell TS, FitzGerald GA, Egan KM, Geraci MW, Reebles RSJ. Prostaglandin I2 analogs inhibit proinflammatory cytokine production and T cell stimulatory function of dendritic cells. J Immunol 2007;178:702-10.

130. Aronoff DM, Carstens JK, Chen GH, Toews GB, PetersGolden M. Short communication: differences between macrophages and dendritic cells in the cyclic AMPdependent regulation of lipopolysaccharide-induced cytokine and chemokine synthesis. J Interferon Cytokine Res 2006;26:827-33. 


\title{
環狀核苗酸磷酸雙酯酶4及其抑制劑於發炎疾病之影響
}

\author{
金秀蓮 丁曉莉 林世昌 ${ }^{1}$
}

第四家族環狀核苷酸磷酸雙酯酶 (PDE4) 是分解 cAMP 的酵素, 在哺乳生物中由四個基因 (PDE4A, PDE4B, PDE4C, PDE4D) 所組成, 可生成二十種以上 PDE4 異構酶。雖然該等酵素具 有高度保留的催化區以及在調控區内序列相似的 UCR1 與 UCR2 區, 但每個基因卻各有其特 殊的生理功能。由於 PDE4 異構酶的組織分布甚廣, 且在不同細胞内的表現與調節各不相同, 因此這些酵素被視爲是細胞内 cAMP 濃度、cAMP 訊息傳導與 cAMP 訊息區域性的主要調控 者。文獻顯示, PDE4 抑制劑可經由增加 cAMP 濃度進而抑制多種免疫細胞的發炎反應, 目前 許多 PDE4 抑制劑已針對不同的發炎疾病進行臨床試驗, 這些抑制劑（包含近來被通過上市的 roflumilast) 雖具有相當的療效, 但均會產生副作用如噁心、嘔吐等, 使施藥劑量受限以致降 低抗發炎的功效。爲此, 研發功效佳、低副作用的 PDE4 抑制劑成爲藥廠努力的重心。近年來 研究報告指出, 利用 PDE4B 選擇性抑制劑應可保有 PDE4 抑制劑的藥效且可降低其副作用, 此外, 研發吸入式或皮膚外用式 PDE4 抑制劑對治療呼吸道發炎疾病或皮膚炎亦是極具潛能的 策略。本文主要綜述 PDE4 異構酶的蛋白質結構與功能關係、PDE4 對免疫細胞發炎反應的影 響，以及 PDE4 抑制劑做爲治療發炎疾病的潛能。(長庚醫誌 2012;35:197-210)

關鍵詞：環狀核苷酸磷酸隻酯酶 4, 發炎作用, 氧喘, 慢性阻塞性肺病, cAMP 訊息傳導

國立中央大學 生命科學系; 國泰醫院 內科部 過敏免疫科

受文日期：民國100年10月12日；接受刊載：民國100年12月12日

通訊作者：金秀蓮教授，國立中央大學 生命科學系。桃園縣320中壢市中大路300號。Tel: (03)4227151轉65066;

Fax: (03)4228482; E-mail: slcj@ncu.edu.tw

通訊作者: 林世昌醫師, 國泰醫院 內科部 過敏免疫科。台北市106仁愛路四段280號。Tel: (02)27082121轉3210;

Fax: (02)27082121轉3211; E-mail: sclin@ cgh.org.tw 